\title{
EFEKTIVITAS DAN DAMPAK PROGRAM NASIONAL PEMBERDAYAAN MASYARAKAT-MANDIRI PERDESAAN (PNPM-MPd) DI KECAMATAN DENPASAR UTARA
}

\author{
Nyoman Kirwati ${ }^{1}$ \\ N. Djinar Setiawina ${ }^{2}$ \\ I.G.W Murjana Yasa ${ }^{3}$ \\ ${ }^{1,2,3}$ Fakultas Ekonomi Universitas Udayana (Unud), Bali, Indonesia \\ email: nyomankirwati@gmail.com
}

\begin{abstract}
ABSTRAK
Tujuan dari penelitian adalah untuk menganalisis efektivitas Program Nasional Pemberdayaan Masyarakat-Mandiri Perdesaan di Kecamatan Denpasar Utara, untuk menganalisis perbedaan terhadap pendapatan, kesempatan kerja untuk rumah tangga sasaran (RTS) sebelum dan setelah mengikuti Program Nasional Pemberdayaan Masyarakat-Mandiri Perdesaan di Kecamatan Denpasar Utara dan untuk mengetahui kelemahan-kelemahan dari Program Nasional Pemberdayaan Masyarakat-Mandiri Perdesaan di Kecamatan Denpasar Utara. Hasil pengujian hipotesis yang dilakukan menunjukkan bahwa efektivitas pelaksanaan Program Nasional Pemberdayaan Masyarakat - Mandiri Perdesaan (PNPM-MP) di Kecamatan Denpasar Utara tergolong sangat efektif ditinjau dari empat indikator yaitu: tujuan program, sasaran program, pendanaan program, dan peruntukan dana program. Ditinjau dari dampak PNPM Mandiri Perdesaan terhadap peningkatan pendapatan masyarakat di Kecamatan Denpasar Utara yang dilakukan menunjukkan bahwa pelaksanaan Program PNPM Mandiri Perdesaan di Kecamatan Denpasar Utarasudah cukup memberikan dampak pada peningkatan pendapatan masyarakat miskin dan peningkatan kesempatan kerja bagi masyarakat miskin. Kesempatan kerja rumah tangga miskin sesudah mendapatkan bantuan Program Nasional Pemberdayaan MasyarakatMandiri Perdesaan (PNPM-MP) di Kecamatan Denpasar Utara berpengaruh positif tehadap peningkatan kesempatan kerja rumah tangga miskin.
\end{abstract}

Kata kunci : efektivitas, PNPM Mandiri Perdesaan, kesempatan kerja, pendapatan.

\begin{abstract}
The purpose of the study was to analyze the effectiveness of the National Program for Community Empowerment-Mandiri Rural in District of North Denpasar, to analyze the differences in income, employment opportunities for poor households before and after attending the National Community Empowerment Program-Mandiri Rural in District of North Denpasar and to identify the weaknesses of the National Program for Community Empowerment in Rural Self- District of North Denpasar. Results of hypothesis testing carried out showed that the effectiveness of the implementation of the National Program for Community Empowerment - Mandiri in Rural Areas (PNPM-MP) in District of North Denpasar as very effective in terms of four indicators namely: the program objectives, program objectives, funding programs, and allocation of funds program. Judging from the impact of PNPM Mandiri to improve household incomes in District of North Denpasar conducted showed that the implementation of the Program PNPM Rural in North Denpasar District had enough impact on increasing incomes of the poor and increase employment opportunities for the poor. Job opportunities after the poor households get help National Community Empowerment Program-Independent Rural (PNPM-MP) in the District of North Denpasar positive effect increasing employment opportunities of poor households.
\end{abstract}

Keywords: effectiveness, PNPM Rural, employment, income. 


\section{PENDAHULUAN}

Kemiskinan yang terjadi di Indonesia dilihat dari tiga pendekatan yaitu kemiskinan alamiah, kemiskinan struktural, dan kesenjangan antar wilayah.Sebagai Negara yang merdeka dan berdaulat, Indonesia berhak menentukan nasib bangsanya sendiri, hal ini diwujudkan dalam bentuk pembangunan (Siagian dalam Rejeki, 2006).Kebijakan politik dan ekonomi yang kurang tepat dan tidak memihak masyarakat miskin menyebabkan masyarakat miskin akan semakin terpinggirkan, sehingga mereka tidak memiliki akses yang cukup ke sumberdaya untuk dapat hidup secara layak, seperti akses ekonomi, akses dalam rangka pemenuhan kebutuhan fisik, akses sosial dan politik sehingga mereka terpaksa hidup dibawah standar hidup yang layak. Semakin memperlemah kondisi masyarakat miskin yang ditandai dengan rendahnya daya saing sumberdaya manusia,lemahnya etos kerja, daya beli yang semakin rendah, bila situasi ini tidak segera diatasi.Masih perlu diteliti secara mendalam mengingat justru angka kemiskinan di Denpasar juga semakin bertambah, kemungkinan karena tidak tepatnya sasaran pelaksanaan program sehingga dapat berimbas pada wilayah Denpasar, karena selama ini diketahui bahwa masyarakat miskin sangat tidak berdaya dalam memperjuangkan program-program yang diberikan oleh pemerintah.

\section{METODE PENELITIAN}

\section{Lokasi Penelitian}

Bertempatdi Desa Ubung dan Peguyangan Di Kecamatan Denpasar Utara, karena Kecamatan Denpasar Utara merupakan kecamatan dengan jumlah 
penerima program PNPM (MPd) terbanyak diantara kecamatan lainnya di Kota Denpasar, dan belum pernah di evaluasi program PNPM di wilayah tersebut sehingga terdapat kesenjangan frekuensi mengenai efektivitas program tersebut dalam pengentasan kemiskinan.

\section{Jenis Data menurut Sifat dan Sumber Data}

Data penelitian ini adalah data primer.Data primer bersumber misalnya usaha dari masyarakat yang memperoleh pembiayaan pembangunan infrastruktur dan lain-lain, serta dokumentasi, dilakukan pengumpulan bahan-bahan tertulis, data berupa dokumen dan studi literatur.Data sekunder dapat dilakukan dengan Observasi, yakni mempelajari dan menganalisa sejumlah bahan-bahan tertulis, baik pendapat para ahli yang dianggap memiliki relevansi terhadap penelitian dan dokumen berkaitan dengan masalah yang dikaji sering diperlukan. Dokumentasi diperoleh dari kantor Camat. Populasi dalam penelitian ini adalah seluruh anggota penerima PNPM (MPd) pada tahun 2014 berjumlah 140 orang tersebar di 2 Desa/kelurahan di Kecamatan Denpasar Utara. Menggunakan pengambilan sampel dengan metode memilih siapa yang kebetulan dijumpai (NonProbability Sampling, yaitu accidental sampling).Sampel berjumlah 78 orang.

\section{Definisi Operasional Variabel}

Definisi operasional variable dapat diuraikan sebagai berikut.

1) Berorientasi pada masyarakat miskin, artinya segala keputusan yang diambil berpihak kepada masyarakat miskin. 
2) Demokratis. Dalam pengambilan keputusan masyarakat mengambil keputusan pembangunan dilakukan secara musyawarah dan mufakat dengan tetap berorientasi pada kepentingan masyarakat miskin,

3) Partisipasi adalah masyarakat berperan aktif dalam proses atau alur tahapan program dan pengawasannya, mulai dari tahap sosialisasi, perencanaan, pelaksanaan, dan pelestarian kegiatan dengan memberikan sumbangan tenaga pikiran atau dalam bentuk materiil,

4) Prioritas.masyarakatmemiliki pilihan untuk memilih kegiatan yang diutamakan dengan mempertimbangkan kemendesakan dan kemanfaatan untuk pengentasan kemiskinan.

5) Otonomi, yaitu masyarakat memiliki hak dan kewenangan mengatur diri sendiri secara mandiri dan bertanggung jawab tanpa intervensi negatif dari luar.

6) Desentralisasi yaitu memberikan ruang yang lebih luas kepada masyarakat untuk mengelola kegiatan pembangunan sektoral dan kewilayahan yang bersumber dari pemerintah pusat dan pemerintah daerah sesuai dengan kapasitas masyarakat.

7) Bertumpu pada pembangunan manusia adalah masyarakat hendaknya memilih kegiatan yang berdampak langsung terhadap upaya pembangunan manusia daripada pembanguan fisik semata.

8) Kesetaraan dan keadilan gender adalah masyarakat baik laki-laki dan perempuan mempunyai kesetaraan dalam perannya di setiap tahap program dan dalam menikmati secara adil manfaat kegiatan pembangunan. 
9) Keberlanjutan adalah bahwa, setiap mengambil keputusan atau tindakan pembangunan mulai dari tahap perencanaan, pelaksanaan, pengendalian dan pemeliharaan kegiatan harus telah mempertimbangkan system pelestariannya.

10) Transparansi dan akuntabel adalah masyarakat memiliki akses yang memadai terhadap segala informasi dan proses pengambilan keputusan sehingga pengelolaan kegiatan dapat dilaksanakan secara terbuka dan dipertanggunggugatkan baik secara moral, teknis, legal maupun administratif.

11) Usaha Produktif adalah dikaitkan dengan pengembangan usaha dan variasi usaha yang dilaksanakan oleh keluarga miskin baik dari segi kuantitas, kualitas, dan jenis usaha.

12) Asset Usaha dikaitkan dengan peningkatan asset usaha baik asset usaha bergerak maupun tidak bergerak yang dapat meningkatkan proses produksi setelah menerima bantuan PNPM-MPd, diukur dalam satuan rupiah.

13) Pendapatan Rumah Tangga sasaran adalah yang diterima rumah tangga sasaran yang menerima bantuan PNPM-MPd, yang diukur dengan rupiah.

14) Kesempatan Kerja Rumah Tangga Sasaran sebelum dan sesudah menerima bantuan PNPM-MPd, yang diukur dengan jam.

\section{Teknik Analisis Data}

\section{1) Analisis Statistik Deskriptif}

\section{2) Analisis Statistik Varian}

Untuk menganalisis tingkat efektivitas dan dampak program PNPM-MPDi Kecamatan Denpasar Utara dipergunakan beberapa analisis antara lain. 
Nyoman Kirwati, N. Djinar Setiawina, dan I.G.W Murjana Yasa. Efektivitas dan Dampak...

1) Untuk mengetahui efektivitas PNPM-MPDi Kecamatan Denpasar Utara menurut Subagyo (2000), digunakan teknik analisis statistik deskriptif sebagai berikut.

Efektivitas $=\frac{\text { Realisasi }}{\text { Target }} \times 100$ persen

Keterangan:

Realisasi : Pencapaian pelaksanaan program

Target : Seluruh anggota kelompok yang mengikuti program

Instrumen penelitian dirancang secara kualitatif dalam kuesioner yang terdiri dari pendapat responden tentang pendapat responden tentang efektivitas program pada tahapan perencanaan program, tahapan pelaksanaan program dan tanggapan responden terhadap pengawasan atau pengendalian program. Tanggapan/ jawaban responden atas pertanyaan dalam kuesioner tersebut akan dikelompokkan dalam dua pernyataan ya (positif) dan pernyataan tidak (negatif), kemudian pernyataan ya (positif) dibandingkan dengan targetdan dikalikan 100 persen maka akan didapat nilai tingkat Efektivitas PNMP- Di Kecamatan Denpasar Utara.

2) Untuk menganalisis dampak PNPM-MPDi Kecamatan Denpasar Utara terhadap pendapatan peserta program, menurut Wirawan (2002).

a) Merumuskan hipotesis 
$\mathrm{H}_{0}: \mu_{\mathrm{d}}=0$; PNPM-MP di Kecamatan Denpasar Utara tidak berpengaruh secara positif dan signifikan terhadap pendapatan pesertaPNPM-MPdi Kecamatan Di Kecamatan Denpasar Utara.

$\mathrm{H}_{1}: \quad \mu_{\mathrm{d}} \neq 0$;PNPM-MPdi Kecamatan Denpasar Utara berpengaruh secara positif dan signifikan terhadap pendapatan pesertaPNPM-MP di Kecamatan Di Kecamatan Denpasar Utara.

b) Menghitung nilai statistik (uji t)

$$
\mathrm{t}_{\mathrm{o}}=\frac{\bar{d}}{S d / \sqrt{n}}
$$

Keterangan:

$$
\bar{d}=\text { Beda nilai rata2 }
$$

$\mathrm{n}=$ Pengamatan berpasangan

$\mathrm{Sd}=$ Simpang baku perbedaan yang dihasilkan suatu perlakuan (standar deviasi) dapat dihitung dengan rumus.

Pengujian secara statistik dilakukan dengan menggunakan taraf nyata (level of significant) dengan syarat uji satu sisisebesar 5 persen, yaitu sisi sebelah kanan. Bila uji t lebih kecil dari $\mathrm{t}$ tabel maka $\mathrm{H}_{0}$ diterima, artinya tidak berdampak terhadap pendapatan peserta PNPM-MP di Kecamatan Denpasar Utara. Sebaliknya apabila $\mathrm{H}_{0}$ ditolak berarti PNPM-MP Di Kecamatan Denpasar Utara 
signifikan berpengaruh positif terhadap pendapatan peserta programPNPM- di Kecamatan Denpasar Utara.Dengan kata lain ada pengaruh positif dan signifikan PNPM-MP Di Kecamatan Denpasar Utara terhadap pendapatan.

2) Untuk menganalisis dampak PNPM-MP di Kecamatan Denpasar Utara terhadap kesempatan kerja pesertaprogram, menurutWirawan (2002), dilakukan pengujian statistik, yaitu uji beda dua rata-rata pengamatan berpasangan dengan tahap-tahap pengujian sebagai berikut.

a) Merumuskan hipotesis

$\mathrm{H}_{0}: \mu_{\mathrm{d}} \leq 0 ; \mathrm{PNPM}-\mathrm{MP}$ di Kecamatan Denpasar Utara tidak berpengaruh positif dan signifikan terhadap kesempatan kerja peserta PNPM-MP di Kecamatan Denpasar Utara.

$\mathrm{H}_{1}: \mu_{\mathrm{d}}>0$;PNPM-MP di Kecamatan Denpasar Utaraberpengaruh positif dan signifikan terhadap kesempatan kerja peserta program PNPM-MP di Kecamatan Denpasar Utara.

b) Menghitung nilai statistik (uji t) dengan menggunakan rumus sebagai berikut.

$$
\mathrm{t}_{\mathrm{o}}=\frac{\bar{d}}{S d / \sqrt{n}}
$$

Keterangan:

$\bar{d}=$ Nilai beda rata-rata

$\mathrm{n}=$ Pengamatan berpasangan

Sd = Simpangan baku perbedaan yang dihasilkan suatu perlakuan (standar deviasi) dapat dihitung dengan rumus: 
Pengujian secara statistik dilakukan dengan menggunakan taraf nyata (level of significant)sebesar 5 persen dengan syarat uji satu sisi, yaitu sisi sebelah kanan.

Bila uji t lebih kecil dari t tabel maka $\mathrm{H}_{0}$ diterima, artinya PNPM-MP di Kecamatan Denpasar Utara tidak berpengaruh terhadap kesempatan kerja peserta PNPM-MP di Kecamatan Denpasar Utara. Sebaliknya apabila $\mathrm{H}_{0}$ ditolak berarti PNPM-MP di Kecamatan Denpasar Utara berpengaruhsecara positif dan memiliki pengaruhyang signifikan akan kesempatan kerja peserta PNPM-MP di Kecamatan Denpasar Utara.

\section{HASIL PENELITIAN}

\section{Analisis Efektivitas (PNPM-MP) Di Kecamatan Denpasar Utara}

Untuk menganalisis efektivitas Program Nasional Pemberdayaan Masyarakat - Mandiri Perdesaan (PNPM-MP) Di Kecamatan Denpasar Utara, dilakukan dengan menyebarkan kuesioner terhadap 120 responden. Untuk mengukur efektivitas Program Nasional Pemberdayaan Masyarakat - Mandiri Perdesaan ini maka digolongkan ke dalam beberapa indikator yaitu : tujuan, sasaran, pendanaan, dan peruntukkan dana program.

\section{Pencapaian Tujuan}

Alat ukur yang digunakan untuk mengetahui kesesuaian pencapaian tujuan program adalah apakah responden mengetahui tujuan program PNPM-MP, apakah responden ikut berpartisipasi dalam perencanaan program PNPM-MP.

Dari Tabel 1 dapat dilihat bahwa 63 orang atau 80,77 persen responden menyatakan mengetahui tujuan program PNPM-MP dan 60 orang atau 76,92 
Nyoman Kirwati, N. Djinar Setiawina, dan I.G.W Murjana Yasa. Efektivitas dan Dampak...

persen responden menyatakan ikut berpartisipasi dalam perencanaan program PNPM-MP.

Tabel 1

Tanggapan Responden Tentang Pencapaian Tujuan Program

\begin{tabular}{clcccc}
\hline \multirow{2}{*}{ No } & \multirow{2}{*}{ Uraian } & \multicolumn{3}{c}{ Jumlah Responden } \\
\cline { 3 - 6 } & & \multicolumn{3}{c}{ Ya } & \multicolumn{2}{c}{ Tidak } \\
\cline { 3 - 6 } & & Orang & Persen & Orang & Persen \\
\hline \multirow{2}{*}{1} & Mengetahui Tujuan Program & 63 & 80,77 & 15 & 19,23 \\
2 & Ikut Berpartisipasi dalam & 60 & 76,92 & 18 & 23,08
\end{tabular}

Sumber : Hasil Penelitian, Tahun 2016 (data diolah)

\section{Pencapaian Sasaran Program}

Sasaran kegiatan program PNPM-MP adalah masyarakat atau rumah tangga miskin. Untuk mengukur pencapaian sasaran program diukur dengan apakah masyarakat penerima manfaat program PNPM-MP memang benar sebagai rumah tangga miskin, dan untuk mengetahui pencapaian sasaran program dilihat pada Tabel 2.

Tabel 2

Tanggapan Responden Terhadap Pencapaian Sasaran Program

\begin{tabular}{clcccc}
\hline \multirow{2}{*}{ No } & Uraian & \multicolumn{3}{c}{ Jumlah Responden } \\
\cline { 3 - 5 } & & \multicolumn{3}{c}{ Ya } & \multicolumn{2}{c}{ Tidak } \\
\cline { 3 - 5 } & Orang & Persen & Orang & Persen \\
\hline \multirow{2}{*}{1} & $\begin{array}{l}\text { Rumah tangga Miskin penerima } \\
\text { manfaat program }\end{array}$ & 61 & 78,21 & 17 & 21,79 \\
\hline
\end{tabular}

Sumber : Hasil Penelitian, Tahun 2016 (data diolah)

Tabel 2 menunjukkan bahwa dari 78 responden yang diteliti 61 orang atau 78,21 persen responden yang termasuk rumah tangga miskin

\section{Ketepatan Pendanaan Program}


Ketepatan pendanaan program diukur dengan apakah dana yang diterima oleh penerima manfaat besaran dananya sesuai dengan usulan proposal, harus utuh tidak termasuk pajak, retribusi atau biaya lainnya, dan apakah waktu pencairan dananya tepat waktu. Untuk mengetahui ketepatan penadanaan program PNPM-MP dilihat pada Tabel 3.

Tabel 3

Tanggapan Responden Terhadap Pencapaian Pendanaan Program

\begin{tabular}{cccccc}
\hline \multirow{2}{*}{ No } & \multirow{2}{*}{ Uraian } & \multicolumn{3}{c}{ Jumlah Responden } \\
\cline { 3 - 6 } & & Orang & Persen & Orang & Persen \\
\hline 1 & Tepat Jumlah Pendanaan Program & 72 & 92,31 & 6 & 7,69 \\
2 & Tepat Waktu Pendanaan Program & & & & \\
2 & & 73 & 93,59 & 5 & 6,41 \\
\hline
\end{tabular}

Tabel 3 menunjukkan bahwa dari 78 responden yang menyatakan tepat jumlah pendanaan 72 orang atau 92,31 persen, dan 73 orang atau 93,59 persen responden menyatakan tepat waktu pendanaannya.

\section{Ketepatan Peruntukan Dana Program}

Untuk mengetahui pencapaian peruntukan program PNPM-MP digunakan alat ukur apakah bantuan yang diterima penerima manfaat dipergunakan untuk kegiatan usaha ekonomis produktif atau untuk kegiatan lainnya. Untuk mengetahui peruntukan dana program PNPM-MP dilihat pada Tabel 4.

Dari Tabel 4 dilihat bahwa dari 78 responden yang diteliti 72 orang atau 92,31 responden yang menyatakan bahwa bantuan yang diperolehnya digunakan untuk membiayai usaha ekonomis produktif, sedangkan 6 orang atau 7,69 persen menyatakan tidak untuk membiayai usaha ekonomis produktif.

\section{Tabel 4}




\section{Tanggapan Responden Terhadap Peruntukan Dana Program}

\begin{tabular}{|c|c|c|c|c|c|}
\hline \multirow{3}{*}{ No } & \multirow{3}{*}{ Uraian } & \multicolumn{4}{|c|}{ Jumlah Responden } \\
\hline & & \multicolumn{2}{|c|}{ Ya } & \multicolumn{2}{|c|}{ Tidak } \\
\hline & & Orang & Persen & Orang & Persen \\
\hline 1 & Untuk Usaha Ekonomi Produktif & 72 & 92,31 & 6 & 7,69 \\
\hline
\end{tabular}

Sumber : Hasil Penelitian, Tahun 2016 (data diolah)

Efektivitas pelaksanaan Program Nasional Pemberdayaan Masyarakat Mandiri Perdesaan (PNPM-MP) dilihat dari indikator capaian tujuan program, ketepatan akan sasaran program, ketepatan penggunaan pendanaan program, ketepatan peruntukan akan dana program, dilihat pada Tabel 1 sampai Tabel 4yaitu antara lain untuk indikator pencapaian tujuan program dari 78 responden yang diwawancarai 73 orang menyatakan mengetahui tujuan program, yang menyatakan ikut berpartisipasi dalam perencanaan program sebanyak 71 orang. Untuk indikator ketepatan sasaran program dari 78 responden yang di wawancarai 71 orang yang menyatakan bahwa penerima manfaat adalah rumah tangga miskin. Untuk indikator ketepatan pendanaan program dari 78 responden yang diwawancarai yang menyatakan tepat jumlah pendanaan program sebanyak 72 orang dan yang menyatakan tepat waktu pendanaan program sebanyak 73 orang. Untuk indikator ketepatan peruntukan dana program dari 78 responden yang diwawancarai 72 orang yang menyatakan menggunakan dana bantuan untuk usaha ekonomi produktif.

Analisis efektivitas Program Nasional Pemberdayaan MasyarakatMandiri Perdesaan (PNPM-MP) dilakukan dengan cara membandingkan antara realisasi dengan target dikalikan 100 persen seperti berikut : 


$$
\begin{aligned}
\text { Efektifitas Program } & =\frac{\text { Realisasi }}{\text { Target }} \times 100 \text { persen } \\
& =\frac{62+60+61+72+73+72}{78 \times 6} \times 100 \text { persen } \\
& =\frac{400}{468} \times 100 \text { persen } \\
& =85,47 \text { persen }
\end{aligned}
$$

Berdasarkan hasil perhitungan matematika dan statistika sederhana tersebut didapat nilai 85,47 persen dan bila digolongkan ke dalam standarisasi efektivitas menurut Litbang Depdagri, maka Program Nasional Pemberdayaan Masyarakat - Mandiri Perdesaan (PNPM-MP) tergolong sangat efektif.

\section{Analisis Dampak Program PNPM-MP Terhadap Pendapatan Rumah tangga} Miskin.

Untuk mengetahui digunakan alat ukur perubahan pendapatan rata-rata rumahtangga miskin penerima manfaat sebelum dan sesudah menerima bantuan program. Dari 78 responden yang diwawancarai 72 orang atau 80,00 persen menyatakan pendapatannya meningkat, dan yang menyatakan pendapatannya tetap sesudah menerima bantuan program PNPM-MP sebanyak 6 orang atau 7,69 persen.

Uji statistik yang digunakan untuk mengetahui dampak PNPM-MP terhadap pendapatan rumahtangga miskin yaitu digunakan uji statistik parametrik beda dua rata-rata pengamatan berpasangan, dengan tingkat kepercayaan 95 persen atau $\alpha=5$ persen dan uji satu sisi diperoleh nilai t tabel $=1,662$ Langkah-langkah uji statistik yang digunakan sebagai berikut : 
1) Menentukan Hipotesis :

Ho : $\partial_{\mathrm{ptn}} \leq 0$ artinya tidak terjadi peningkatan pendapatan padarumah tangga miskin setelah program PNPM-MP atau program PNPM-MP tidak memberikan pengaruh akan pendapatan rumahtangga miskin di Kecamatan Denpasar Utara.

$\mathrm{Hi}: \partial_{\mathrm{ptn}}>0$ artinya terjadi peningkatan pendapatan rumahtangga miskin sesudah program PNPM-MP atau program PNPMMP berpengaruh secara signifikan terhadap pendapatan rumahtangga miskin di Kecamatan Denpasar Utara.

\section{Analisis Dampak PNPM-MP terhadap Kesempatan Kerja Rumah tangga}

\section{Miskin}

Diukur dengan perubahan jumlah waktu dalam satuan jam sebelum dan sesudah menerima bantuan program PNPM-MP. Dari 78 responden yang diwawancarai, responden yang menyampaikan kesempatan kerja meningkat sesudah mendapat bantuan atau menerima manfaat program PNPM-MP sebanyak 76 orang atau 84,44 persen dan yang menyatakan kesempatan kerja tetap setelahmendapatkan bantuan atau menerima manfaat program PNPM-MP sebanyak 44 orang atau 15,56 persen.

Uji statistik yang digunakan untuk mengetahui dampak PNPM-MP terhadap kesempatan kerja rumahtangga miskin yaitu digunakan uji statistik parametrik beda dua rata-rata pengamatan berpasangan, dengan tingkat kepercayaan 95 persen atau $\alpha=5$ persen dan uji satu sisi diperoleh nilai t tabel $=$ 1,662 
Langkah-langkah uji statistik yang digunakan sebagai berikut :

1) Menentukan Hipotesis :

$$
\begin{aligned}
\text { Ho }: \partial_{\mathrm{KKj}}<0 \quad & \text { artinya tidak terjadi peningkatan kesempatan kerja } \\
& \text { rumahtangga miskin sesudah program PNPM-MP } \\
& \text { atau program PNPM-MP tidak berpengaruh terhadap } \\
& \text { kesempatan kerja rumahtangga miskin Di } \\
& \text { Kecamatan Denpasar Utara. } \\
\mathrm{Hi}: \partial_{\mathrm{KKj}}>0 \quad & \text { artinya terjadi peningkatan kesempatan kerja } \\
& \text { rumahtangga miskin sesudah program PNPM-MP } \\
& \text { atau program PNPM-MP berpengaruh secara } \\
& \text { signifikan terhadap kesempatan kerja rumahtangga } \\
& \text { miskin Di Kecamatan Denpasar Utara. }
\end{aligned}
$$

\section{Kelemahan-kelemahan PNPM Mandiri}

Alasan pertama dan yang utama untuk menghentikan PNPMMandiri adalah karena penyelenggaraan program ini menabrak UU Nomor 13 Tahun 2011 tentang Penanganan Fakir Miskin (UU-PFM). Program tersebut, yang berangkat dari keinginan mempercepat penanggulangan kemiskinan berdasarkan Perpres dan Permen (Peraturan Menteri), wajib hukumnya mentaati peraturan yang lebih tinggi, yaitu undang-undang.Selain merupakan amanat konstitusi, UU-PFM hadir untuk menertibkan pengaturan penanggulangan kemiskinan yang masih banyak tersebar di berbagai peraturan perundang-undangan sehingga terhimpun secara integral dan terkoordinasi. Jika mau sadar hukum, apa boleh buat, TNP2K harus dibubarkan atau setidaknya direkonstruksi agar tidak menyalahi undang-undang. 
Alasan kedua, dana triliunan rupiah PNPM-Mandiri tidak murni dari anggaran pendapatan belanja negara dan daerah, melainkan dari pinjaman Bank Dunia.

Mengapa berutang hanya untuk menutupi beban anggaran subsidi? Utang pemerintah sampai dengan akhir 2011 mencapai Rp 1.803,49 triliun, meningkat Rp 126,64 triliun dalam satu tahun saja dibanding 2010 sebesar Rp 1.676,85 triliun.Sulit dikatakan PNPMMandiri melakukan banyak pembangunan proyek infrastruktur yang produktif karena programnya merambah ke semua bidang kerja yang terkesan cuma bagi-bagi bantuan sosial, sehingga kesimpulan akhir adalah kuatnya dugaan untuk "membiayai" perilaku konsumtif dan inefisiensi (tidak efisien).

Alasan ketiga, jauh dari makna pemberdayaan masyarakat. Jika waktu itu tidak ada kenaikan harga BBM tidak ada BLT, tidak akan ada bantuan langsung masyarakat, dan tidak akan ada PNPM-Mandiri.Sejatinya, program ini tidak pernah direncanakan, karena itu wajar menjadi tidak terarah dan tidak berkelanjutanterucapkan oleh wapres hanya sampai 2014.Tiadanya perencanaan juga tercermin dari nama lembaga yang menanganinya berubah-ubah, demikian pula ketuanya, dari semula seorang menko Kesra berganti wakil presiden. Bagaimana hendak memberdayakan masyarakat secara luas, jika untuk penguatan kelembagaannya sendiri saja tidak mampu dilakukan?

Keempat, tumpang tindih dengan proyek-proyek pembangunan lain karena daya jelajah PNPMMandiri yang tiada batas. Ambil contoh PNPM-Mandiri perdesaan yang dikelola Kementerian Dalam Negeri dengan anggaran pada 2011 mencapai 
Rp 9,6 triliun, lebih 50 persen dipergunakan untuk membangun akses transportasi berupa jalan, sektor pendidikan 11 persen, dan kesehatan 10 persen.

Kalau pemberdayaan masyarakat desa diartikan Kemendagri sebagai pembangunan fisik, bagaimana dengan peran Kementerian PU, Kemendikbud, dan Kemenkes di daerah (desa) itu?Karut-marut anggaran semacam itu membuka peluang terjadinya double posting untuk satu objek pembangunan, dan itu berarti pemborosan.

Kelima, PNPM sangat politis. Jika penanggulangan kemiskinan adalah salah satu bidang dalam rencana pembangunan jangka menengah (RPJM) 20102014, maka "sambil berenang minum air", pemerintah secara sadar melaksanakan kewajiban (seolah) menyejahterakan rakyat dengan sasaran kemiskinan sebagai objek belaka. PNPM Perdesaan dan sejenisnya menjadi magnet pusat, melibatkan gubernur dan bupati/walikota, menjangkau pemerintahan provinsi, kabupaten/kota hingga kecamatan. Program ini jadi idaman ('bancakan') daerah, terlebih keadaan pemerintahan daerah (pemda) yang masih sangat bergantung pada dana perimbangan dari APBN.

\section{Pembahasan}

Efektivitas Program Nasional Pemberdayaan Masyarakat - Mandiri Perdesaan

Program Nasional Pemberdayan Masyarakat - Mandiri Perdesaan adalah salah satu program penanggulangan kemiskinan yang bertujuan meningkatkan kesejahteraan dan kesempatan kerja masyarakat miskin di perdesaan dengan 
mendorong kemandirian dalam pengambilan keputusan dan pengelolaan pembangunan serta meningkatkan partisipasi masyarakat khususnya masyarakat miskin mulai dari perencanaan, pelaksanaan, pemantauan dan pelestarian pembangunan. Dengan demikian masyarakat bukan lagi sebagai obyek pembangunan melainkan sebagai subyek pembangunan, masyarakat diberikan peluang memilih dan menentukan akan keperluannya sendiri dengan mencari dan memanfaatkan potensi yang mereka miliki dan gunakan melalui penguatan peran institusilocal di masyrakat atau pelaku-pelaku program lokal, sedangkan pemerintah berperan sebagai fasilitator dalam pencapaian tujuannya.

Achnes et al (2012) juga menjelaskan faktor-faktor yang menyebabkan ketidakberhasilan implementasi PNPM dalam meningkatkan kesejahteraan masyarakat dipengaruhi oleh komunikasi yang kurang dipahami oleh masyarakat, ketidakjelasan dan ketidakkonsistenan petugas dalam menyampaikan informasiinformasi. Struktur birokrasi yang sulit untuk dipahami dan kurang sistematis. Kemudian aspek fragmentasi dari luar yang terlalu ikut campur dalam pelaksanaan.

Wibowo (2011) juga mengemukakan bahwa hambatan yang sering dihadapi di lapangan ketika mewujudkan partisipasi masyarakat dalam mewujudkan keberhasilan pembangunan adalah karena belum dipahaminya makna atau konsep yang sebenarnya dari partisipasi oleh pihak perencana dan pihak pembangunan.

\section{Pencapaian Tujuan Program}


Efektivitas kegiatan program PNPM-MP ditinjau dari pencapaian tujuan program dapat dilihat pada Tabel 2. Dari tabel tersebut dapat diketahui bahwa responden memberikan jawaban yang cukup baik, terbukti dari 78 responden yang diteliti 73 orang atau 92,22 persen menyatakan mengetahui tujuan program PNPM-MP, 5 orang atau 7,78 persen menyatakan tidak mengetahui tujuan program PNPM-MP, dan 71 orang atau 90,00 persen responden menyatakan ikut berpartisipasi dalam perencanaan program PNPM-MP, 7 orang atau 10,00 persen menyatakan tidak ikut berpartisipasi dalam perencanaan program PNPM-MP. Ini artinya bahwa tujuan program PNPM-MP dapat digolongkan cukup efektif, semua tahapan program dapat dilaksanakan dengan baik terutama dari tahap perencanaan yang kegiatannya dimulai dari penggalian gagasan ditingkat banjar kemudian dilanjutkan dengan musyawarah di tingkat desa dalam rangka perencanaan usulan kegiatan program dan selanjutnya dilakukan musyawarah antar desa di tingkat kecamatan untuk mengkompetisikan usulan desa dan menentukan kegiatan program, selalu melibatkan segenap unsur masyarakat terutama masyarakat miskin, sehingga mereka mengetahui program PNPM-MP secara jelas dan ikut berpartisipasi dalam setiap kegiatan program. Disamping itu juga pendampingan program oleh para fasilitator, pendamping lapangan dan pelaku program di tingkat desa bisa dikatakan berjalan baik. Pemanfaatan media komunikasi dalam rangka sosialisasi program terutama papan informasi PNPM-MP dan media rapat juga bisa dikatakan sudah dimanfaatkan dengan baik.

Menurut Nasdian (2006) faktor-faktor yang menghambat pemberdayaan dan partisipasi serta menjadi penyebab mengapa masyarakat lapisan bawah di 
tingkat komunitas tidak berdaya menghadapi lapisan yang lebih kuat perlu dicermati dan diperhatikan dengan baik. Kendala upaya pemberdayaan dan meningkatkan partisipasi warga komunitas pada dasarnya dapat ditelaah dari dimensi struktural-kultural.

\section{Pencapaian Sasaran Program}

Sasaran kegiatan program PNPM-MP adalah masyarakat atau rumahtangga miskin. Efektivitas kegiatan program PNPM-MP ditinjau dari ketepatan sasaran program dapat dilihat pada Tabel 3. Dari tabel tersebut dapat diketahui bahwa dari 78 responden yang diteliti 71 orang atau 78,89 persen responden adalah rumahtangga miskin, dan 49 orang atau 21,11 persen responden bukan rumahtangga miskin. Tidak tepatnya sasaran program sebanyak 19 orang atau 21,11 persen dari 78 responden yang diteliti menunjukkan bahwa masih belum optimalnya para pelaku program PNPM-MP maupun jajaran birokrasi dalam menerapkan prinsip-prinsip dasar PNPM-MP. Namun demikian sesuai dengan hasil penelitian ini seperti tersaji pada Tabel 3 bahwa pencapaian sasaran program PNPM-MP menunjukkan hasil termasuk dalam katagori sangat efektif.

\section{Pencapaian Pendanaan Program}

Pendanaan program kegiatan kepada desa disalurkan berdasarkan usulan kegiatan yang tertuang dalam proposal yang disusun oleh tim pengelola kegiatan di desa yang sebelumnya didahului oleh berbagai tahapan proses di desa. Dana program antara lain dana yang berasal dari APBD harus dicairkan terlebih dahulu kepada masyarakat, selanjutnya diikuti dengan pencairan dana yang berasal dari APBN.Besaran dana Bantuan Langsung Masyarakat (BLM) yang dicairkan ke 
masyarakat harus utuh tidak termasuk pajak, retribusi atau biaya lainnya. Dari hasil penelitian terhadap ketepatan pendanaan program seperti pada Tabel 4 bahwa dari 78 responden yang diteliti yang menyatakan tepat jumlah pendanaan program sebanyak 82 orang atau 91,11 persen dan yang menyatakan tepat waktu pendanaan program sebanyak 83 orang atau 92,22 persen. Dari hasil tersebut menunjukkan bahwa ketepatan pendanaan program PNPM-MP ini tergolong dalam katagori sangat efektif.

\section{Ketepatan Peruntukan Dana Program}

Dana program yang diberikan kepada masyarakat penerima manfaat melalui BLM (Bantuan Langsung Masyarakat) digunakan untuk kegiatan usaha ekonomis produktif dan bukan untuk membiayai konsumsiDari hasil penelitian seperti terlihat pada Tabel 5 bahwa dari 78 responden yang diteliti 72 orang atau 92,31 persen responden menyatakan menggunakan bantuan dana program untuk usaha ekonomis produktif, dan 6 orang atau 7,69 persen responden menyatakan tidak untuk usaha ekonomis produktif, seperti membiayai konsumsi dan lainnya. Berdasarkan hasil penelitian tersebut berarti peruntukan dana program PNPM-MP tergolong sangat efektif. Efektivitas Program Nasional Pemberdayaan Masyarakat - Mandiri Perdesaan dilihat dari indikator tujuan program, sasaran program, pendanaan program, dan peruntukan dana program berdasarkan hasil penelitian tergolong sangat efektif dengan nilai rata-rata ketepatan peruntukan dana program sebesar 89,26 persen.

\section{Dampak Program PNPM-MP}




\section{Dampak Program Nasional Pemberdayaan Masyarakat - Mandiri Perdesaan (PNPM-MP) terhadap Pendapatan Rumah tangga Miskin}

Berdasarkan uji statistik tersebut menunjukkan bahwa PNPM-MP berpengaruh secara signifikan terhadap pendapatan rumah tangga miskin Di Kecamatan Denpasar Utara. Hal ini dapat dipahami dari 78 responden 72 orang atau 92,30 persennya menyatakan bahwa bantuan dana program digunakan untuk usaha ekonomis produktif seperti di tunjukkan pada Tabel 5, dengan bantuan dana untuk penambahan modal usaha tersebut dapat memicu semangat kerja rumah tangga miskin sebagai penerima manfaat disamping dapat mempeluas atau memperbesar usahanya, sehingga berdampak pada peningkatan pendapatan mereka.

Pendapatan rumah tangga miskin setelah diasumsikan 50 persen dipengaruhi oleh PNPM-MP mengalami peningkatan rata-rata sebesar 10,26 persen dari sebelum menerima bantuan PNPM-MP sebesar Rp. 830.622,22 menjadi Rp. 915.877,78 setelah menerima bantuan PNPM-MP. Menurut berita ekonomi harian Bali Post 27 Januari 2013 disebutkan bahwa proyeksi angka inflasi Bali tahun 2013 sebesar 6,6 persen atau rata-rata 0,55 persen perbulan dan angka pertumbuhan ekonomi Bali tahun 2013 sebesar 6,3 persen atau rata-rata 0,525 persen perbulan. Angka-angka tersebut merupakan proyeksi pertumbuhan ekonomi makro tahun 2013 yang diterbitkan oleh Bank Indonesia Denpasar. Jika dikaitkan dengan angka inflasi 6,6 persen atau 0,55 persen perbulan maka pendapatan rata-rata riil rumah tangga miskin menjadi selisih dari pendapatan rata-rata nominal rumah tangga miskin dengan hasil kali angka inflasi yaitu 
menjadi sebesar Rp. 865.504,00 masih terjadi peningkatan pendapatan rata-rata sebesar Rp. 34.881,78 (4,2 persen) dari pendapatan rata-rata sebelum menerima bantuan PNPM-MP. Jika dibandingkan dengan proyeksi angka pertumbuhan ekonomi Bali tahun 2013 sebesar 0,525 persen terhadap peningkatan pendapatan rata-rata riil rumah tangga miskin sebesar 4,2 persen, ternyata peningkatan pendapatan rata-rata riil rumah tangga miskin masih jauh lebih besar. Ini menandakan bahwa program PNPM-MP sangat menarik untuk diikuti oleh masyarakat, juga berarti sistem pembangunan partisipatif yang dikembangkan melalui PNPM-MP ini berhasil dalam meningkatkan pendapatan rumah tangga miskin Di Kecamatan Denpasar Utara. Jika dibandingkan dengan upah harian buruh bangunan untuk daerah Kabupaten Di Kecamatan Denpasar Utara yaitu sebesar Rp. 40.000,00/hari kerja (8 jam) atau Rp. 5000,00 perjam maka pendapatan rata-rata riil rumah tangga miskin Rp. 865.504,00 (Rp. 28.850,13/hari atau Rp. 5008,70/jam) dan pendapatan rata-rata nominal rumah tangga miskin Rp. 915.877,78 (Rp. 30.529,26/hari atau Rp. 5.300,22/jam) ternyata pendapatan ratarata perjam rumah tangga miskin cenderung lebih besar, dari sisi peningkatan kesempatan kerja juga PNPM-MP menarik untuk dijalankan pada masyarakat miskin. Untuk profesi buruh bangunan masih ada ketidakpastian kontinuitas pekerjaan, pada suatu saat bisa tidak bekerja/menganggur karena proyek sudah selesai sementara menunggu pekerjaan/proyek lainnya, ini artinya penghasilan buruh bangunan menjadi berkurang.

Berdasarkan analisa tersebut menunjukkan bahwa peran PNPM-MP sebagai salah satu program yang bertujuan untuk mengentaskan kemiskinan layak 
Nyoman Kirwati, N. Djinar Setiawina, dan I.G.W Murjana Yasa. Efektivitas dan Dampak...

untuk dilaksanakan namun masih perlu ditingkatkan pelaksanaannya Di Kecamatan Denpasar Utara, dan rumah tangga miskin untuk keluar dari belenggu kemiskinan masih perlu dan terus diberdayakan dari segala bidang terutama untuk meningkatkan pendapatannya melalui usaha-usaha ekonomi produktif seperti peternakan, jasa/kerajinan, dagang, pertanian, dan lain-lain.

\section{Dampak Program Nasional Pemberdayaan Masyarakat - Mandiri Perdesaan (PNPM-MP) terhadap Kesempatan Kerja Rumah tangga Miskin}

Hasil penelitian menunjukkan bahwa dari 78 responden, yang menyatakan kesempatan kerjanya meningkat sesudah mendapatkan bantuan program PNPMMP sebanyak 66 responden atau 84,62 persen, dan yang menyatakan kesempatan kerjanya tetap sesudah mendapatkan bantuan program PNPM-MP sebanyak 12 atau 15,38 persen. Uji statistik terhadap kesempatan kerja rumah tangga miskin sebelum dan sesudah menerima bantuan program PNPM-MP ini menunjukkan hasil yang baik juga yaitu program PNPM-MP berpengaruh secara signifikan terhadap peningkatan kesempatan kerja rumah tangga miskin. Terjadi peningkatan kesempatan kerja ini dikarenakan adanya penambahan modal untuk usaha rumah tangga miskin sehingga dapat memperluas dan mengembangkan usahanya dengan demikian juga dapat menambah jam kerjanya atau kesempatan kerjanya. Seperti rumah tangga miskin yang pekerjaan utamanya adalah pedagang kecil, dengan tambahan modalnya digunakan untuk membeli ternak babi atau sapi, maka disamping sebagai pedagang kecil juga sebagai peternak dengan demikian kesempatan kerjanya bertambah. Rata-rata jam kerja rumahtangga miskin perbulan yaitu 172,83 jam atau 5,76 jam /hari, masih lebih sedikit jika 
dibandingkan dengan jam kerja buruh bangunan yaitu 8 jam/hari. Ini berarti produktivitas rumah tangga miskin masih rendah, untuk itu perlu ditingkatkan melalui penciptaan lapangan kerja.

Adanya keaktifan warga dalam pemberian ide-ide pada tahap perencanaan dinilai sangat penting, selain itu adanya kesadaran dan rasa kepemilikan yang tinggi dari masyarakat dibutuhkan dalam tahap pelaksanaan, adanya manfaat yang dirasakan masyarakat dan keikutsertaan masyarakat dalam menilai hasil kerja pada tahap evaluasi merupakan hal terpenting yang harus ada dalam tahapan partisipasi (Girsang 2011). Azimi (2013) juga menjelaskan bahwa dalam tahap pelaksanaan dan tahap evaluasi masyarakat masih memiliki keterlibatan yang sangat rendah. Hal ini dikarenakan partisipasi yang berasal dari stakeholders yaitu pihak swasta masih sangat tinggi, sehingga hal ini membuat masyarakat kurang membuat taraf hidup masyarakat menjadi lebih baik dan tidak ada rasa memiliki dalam menjalankan program pemberdayaan. Dari pernyataan tersebut dapat dilihat pentingnya pelibatan masyarakat dari mulai tahap perencanaan hingga tahap evaluasi, yang ditujukan agar masyarakat mampu menjalankan program pemberdayaan dengan baik dan merasa memperoleh peningkatan taraf hidup dari program yang dilaksanakan.

Dengan demikian pelaksanaan PNPM Mandiri Perdesaan di Kecamatan Denpasar Utara berdampak secara positif baik terhadap peningkatan akanpendapatan masyarakat maupun penciptaan peluang kerja bagi penduduk miskin. Namun demikian peningkatan pendapatan tersebut masih dirasakan kurang. Hal ini disebabkan masih ada penggunaan bantuan tersebut untuk 
kegiatan lainnya bukan hanya untuk menambah modal usaha. Hal inilah yang memang terjadi pada penduduk miskin. Dengan efektifnya pelaksanaanPNPM Mandiri Perdesaan diharapkan situasi yang serba kekurangan tersebut secara bertahap akan dapat dikurangi atau dihapus sehingga masyarakat dapat berdaya dan mandiri sehingga dapat memperjuangkan hak-haknya karena sebenarnya semua masyarakat miskin memiliki hak yang sama dengan anggota masyarakat lainnya. Penelitian terdahulu dari saudara Ketut Kuta (2005) tentang Efektifitas Program Kelompok Belajar Usaha dalam Penanggulangan Kemiskinan, bisa dimanfaatkan. Penduduk miskin yang memilik pendidikan rendah dapat belajar melalui kelompok ini sehingga kualitasnya dapat bertambah yang nantinya akan berdampak pada peningkatan pendapatan maupun kesempatan kerja.

\section{Simpulan}

Berdasarkan hasil penelitian dan pembahasan dari bab - bab terdahulu terhadap efektivitas dan dampak Program Nasional Pemberdayaan MasyarakatMandiri Perdesaan (PNPM-MP) di Kecamatan Denpasar Utara, dapat disimpulkan sebagai berikut :

1) Efektivitas pelaksanaan Program PNPM-MP di Kecamatan Denpasar Utara tergolong sangat efektif ditinjau dari empat indikator yaitu : tujuan, sasaran, pendanaan, dan peruntukan dana program.

2) Dilihat dari dampak/pengaruh PNPM Mandiri Perdesaan terhadap peningkatan kesejahteraan masyarakat di Kecamatan Denpasar Utara yang dilakukan menunjukkan bahwa pelaksanaan Program PNPM Mandiri Perdesaan di Kecamatan Denpasar Utarasudah cukup memberikan 
dampak/pengaruh pada peningkatan akan pendapatan masyarakat miskin dan peningkatan kesempatan kerja bagi masyarakat miskin. Namun peningkatan pendapatan dirasakan masih belum signifikan karena kurangnya modal usaha dan minimnya peningkatan ketrampilan usaha yang mengakibatkan rendahnya nilai jual produksi. Prioritas program harus lebih banyak menyasar pembangunan fisik. Meskipun pembangunan fisik dapat pula menyerap tenaga kerja lokal di desa dan secara langsung meningkatkan pendapatan buruh dan tukang, namun tidak semua masyarakat miskin berprofesi sebagai tukang dan buruh bangunan. Kesempatan kerja rumah tangga miskin sesudah mendapatkan bantuan Program PNPM-MP di Kecamatan Denpasar Utara berpengaruh positif tehadap peningkatan kesempatan kerja rumah tangga miskin.

3) Tumpang tindih dengan proyek-proyek pembangunan lain karena daya jelajah PNPM Mandiri yang tiada batas. Anggaran semacam itu membuka peluang terjadinya double posting untuk satu objek pembangunan, dan itu berarti pemborosan.

\section{Saran :}

1) Dari variabel efektivitas program yang digunakan dalam penelitian ini, tampak pada variabel yang berkaitan dengan ketepatan sasaran program masih perlu mendapat perhatian oleh para pelaku PNPM-MP maupun jajaran birokrasi dalam menerapkan prinsip-prinsip dasar PNPM-MP yaitu sesuai dengan acuan program diantaranya berorientasi pada masyarakat miskin yaitu segala keputusan kegiatan program yang diambil berpihak 
kepada masyarakat miskin, dan skala prioritas yaitu memilih kegiatan yang diutamakan dengan mempertimbangkan kemendesakan dan kemanfaatan untuk pengentasan kemiskinan.

2)Dalam pelaksanaan PNPM Mandiri Perdesaan di Kecamatan Denpasar Utara dampak terhadap peningkatan pendapatan masyarakat miskin belum signifikan, oleh karena itu masih perlu difokuskan untuk membagi proporsi yang seimbang antara berbagai bidang, baik itu bidang ekonomi, bidang sosial dan bidang lingkungan, sehingga kegiatan terssebut dapat memberi peluang lebih maksimal bagi rumah tangga miskin untuk memperoleh pekerjaan dan penghasilan. Begitu pula masyarakat agar selalu ditempatkan sebagai pelaku pembangunan dengan keterlibatan lakilaki dan perempuan yang setara, sehingga akan dapat menyuarakan prioritas kegiatan yang seimbang pemenuhan kebutuhan bidang ekonomi, bidang sosial dan bidang lingkungan sehingga ada peluang memperoleh pekerjaan, peningkatan kapasitas pengetahuan dan penghasilan untuk seluruh masyarakat desa sehingga dapat meringankan beban ekonomi keluarga masyarakat miskin secara berkelanjutan.

3)PNPM MP mungkin akan ditiadakan saat ini. Namun perlu ada kesinambungan dilakukan dan terus di upayakan untuk disempurnakan sebagai ruang publik dan sebagai alat untuk proses perencanaan pembangunan yang partisipatif, transparan dan akuntabel di tingkat Desa. Dengan disahkannya UU No 6 Tahun 2014 tentang desa adalah momentum dan peluang besar bagi pembangunan desa dan masyarakat 
desa. Proses perencanaan PNPM Perdesaan harus lebih berorientasi lebih besar untuk kepentingan masyarakat miskin, demokratis dan mendorong keterlibatan aktif perempuan. Perencanaan dan pelaksanaan program yang dihasilkan melalui PNPM Perdesaan harus selalu berdasarkan skala proritas kebutuhan desa dan masyarakat desa khususnya masyarakat miskin dengan memaksimalkan sumberdaya desa, masyarakatnya sebagai pelaku aktif pembangunan dan mengoptimalkan kekuatan sendiri, sehingga dapat segera terwujudnya masyarakat desa yang mandiri, berkeadilan dan bermartabat di Kecamatan Denpasar Utara.

\section{REFRENSI}

Adi, I. R. Departemen Ilmu Kesejahteraan Sosial, Fakultas Ilmu Sosial dan Ilmu Politik, Universitas Indonesia, 2005, Kemiskinan Multidimensi, 29 Desember 2010, E-mail: adi1126@yahoo.com

Aisyiah, 2001. Potret Kemiskinan Jurnal Ekonomi Pembangunan, Surakata FE UMS, Vol $2(8), 62-84$.

Anonim, tt. Efektivitas Program Pemberdayaan Usaha pada Program Gerakan Terpadu Pengentasan Kemiskinan terhadap Pendapatan Rumah tangga Miskin (studi kasus di desa Wates dan Desa Bendo, Kecamatan Pagu, Kabupaten Kediri), Jurnal skripsi.com23 Juni 2013, http://jurnalskripsi.com

Akyeampong, K,. Djangmah, J., Seidu, A., Oduro,A. and Hunt,F. 2007 Access to Basic Education In Ghana: The Evidence And The Issues. Available At www.createrpc.org

, Ahmad Wito, 2000, Efektivitas Program Penanggulangan Kemiskinan dalam Pemberdayaan Masyarakat Perdesaan, Yogyakarta: UGM

Sudira, I Made. 2004, Evaluasi Program Penanggulangan Kemiskinan (Studi Kasus di Kecamatan Tabanan Kabupaten Tabanan), Tesis Program Pasca Sarjana Magister Ekonomi Pembangunan, Denpasar: Universitas Udayana.

Sugiono. 2008. Metode Penelitian Bisnis, Bandung: Alfabeta. 
Sugiarta, Eddy. 2007. Teori Kesejahteraan Sosial Ekonomi dan Pengukurannya. Jurnal Eksekutif. Vol. 4. No 2

Sulekale, D.D. 2003. Pemberdayaan Masyarakat Miskin di Era Otonomi Daerah, 2 April 2010, http://www.ekonomirakyat.org/edisi-14/artikel-2.htm.

Suyanto, B. 2010. Kemiskinan dan Pemberdayaan Masyarakat Miskin, Jurnal Masyarakat Kebudayaan dan Politik, Vol. 14. No. 4.Hal 30. 2 April 2013. $\quad$ http://mkp.fisip.unair.ac.id/index.phpoption=comcontent \&view $=$ article \&id $=87$

Umar, Husein. 2004. Metode Penelitian untuk Skripsi dan Tesis Bisnis. Raja Grafindo Persada, Jakarta.

Wibowo R. 2011. Pendekatan partisipatif masyarakat terhadap implementasi Program Nasional Pemberdayaan Masyarakat (PNPM) Mandiri. Jurnal Administrasi Bisnis. [Internet]. [diunduh tanggal 10 Oktober 2013]. 8 (2). Dapat diunduh dari:http://repository.upnyk.ac.id/6219/2/Rudi_Wibowo_Naskah.pdf

Wijono WW. 2005. Pemberdayaan Lembaga Keuangan Mikro Sebagai Salah Satu Pilar Sistem Keuangan Nasional : Upaya Kongkrit Memutus Mata Rantai Kemiskinan, Kajian Ekonomi dan Keuangan, Review Jurnal Edisi Khusus. Nopember 2010 http://www.fiskal.depkeu.go.id/webbkt/ kajian persen 5 cwiloejo-1.pdf.

Zoe Oxaal, Education and Poverty: A Gender Analysis. Report Prepared for the Gender Equality Unit, Swedish International Development Coorporation Agency (Sida), Juni 1997 http://www.ids.ac.uk/bridge/ 